dating - and his recognition of their place within a more disciplined approach are at least as important.

The author's emphasis is perhaps a more personal one, although she copes well and expertly (being an archaeologist herself) with Wheeler's excavations and research. She is concerned to see Wheeler as a person, dealing as much with the private life (and many loves) as with the public achievement. She begins: "Mortimer Wheeler will rise from these pages as a Hero

IMAGE
UNAVAILABLE
FOR
COPYRIGHT
REASONS

Mortimer Wheeler - creator of a discipline.

figure. Of that I feel sure even as I write the very first words of my book". Certainly the remarkably varied career - yet singleminded in its devotion to archaeology - is admirably told. Her earlier chapters and description of the war years inevitably owe a great deal to the autobiography. But surprisingly, perhaps, it is the portrait of Rik Wheeler in his old age, as he is remembered by many today (including myself) which seems the most compelling, indeed moving. Those same qualities of panache, of awareness of the effect of the moment, which may have raised eyebrows (and indeed aroused some enmities) earlier, and which caught the attention of millions of viewers in the 1950s, made him the most splendidly vivacious good company in his seventies and eighties, and a friend and encouragement to many half a century younger than he. They come over well in this affectionate portrait.

Whecler came to archaeology with a military briskness of mind which helped him to make the subject, in the scientific as well as the organizational meaning of the term, a discipline. Perhaps just as important, he brought with him a zest and a gusto which made it, in a real and un-trivial sense, entertaining.

\title{
Grounds for doubting the pessimists
}

\section{P. D. Henderson}

The Ultimate Resource. By Julian L. Simon. Pp.412. US ISBN 0-691-09389-X; UK ISBN 0-85520-440-0. (Princeton University Press/Martin Robertson:1981.) $\$ 14.50, £ 9.50$.

WRITING in 1933, Keynes said of Malthus's Essay on the Principle of Population that "it attracted immediate attention, and the warfare of pamphlets instantly commenced ... . which for 135 years has never ceased". Hostilities have continued during the half-century since Keynes wrote, and Julian Simon's new 400-page volume is a reminder that not only pamphlets are involved. The issues that Malthus raised so provocatively in 1798 are still live, unsettled and highly contentious.

The main issues are two: first, the extent to which it is possible for human societies to achieve material progress; and second, the effects of population changes on their prospects of doing so. In relation to these, it is still possible to think of the main battleline as drawn between Malthusians and anti-Malthusians, though as in other spheres of conflict there are wide differences of view within each of the two factions.

Following in the steps of the master, modern Malthusians are pessimistic on both issues, or at least inclined to emphasize dangers and limitations rather than opportunities. As to material progress, the possibilities for growth in output are seen as restricted in any given society, and for the human race as a whole, because of constraints on the availability of land or natural resources. From this arises the threat of overpopulation. It is admitted that population growth will create a larger labour force - more hands, as well as more mouths - and thus tend to raise the level of potential output; but given the constraints imposed by nature, not much can be expected from this positive effect. Thus higher rates of population growth will often be a drag on material progress. Conversely, lower population growth may hold the key to sustainable prosperity.

By contrast, anti-Malthusians take a more sanguine view. They are sceptical about limits to growth, while at the same time many of them stress the positive effects of population increase on a socicty's capacity to produce goods and services. These are the two main themes of Simon's interesting and readable book. The author pours scorn on current pessimism and prophecies of doom despite onc or two favourable references to Malthus himself - and the book may be described as a scholarly polemic.

Most of the argument is directed to the two issues identified above. Part One ("Towards Our Beautiful Resource Future") considers the possible scarcity of natural resources, and deals successively with minerals, food supplies, land, energy, environmental pollution and conservation. On all of these Simon points out, with some well chosen and carefully presented statistics, that the evidence of recent decades is more encouraging than is generally realized. Thus minerals, food products and energy supplies have over the past century become less costly in relation to wages; world food supplies have grown more rapidly than population; while the expectation of life, which he regards as the best single indicator of pollution, has risen all over the world. In Simon's judgement, all these favourable trends are likely to be maintained into the indefinite future: in the case of the cost of raw materials, he makes an engaging offer to back his assessment with money, by accepting bets from readers who take a different view. He thus rejects completely the notion that economic growth is constrained by the availability or cost of resources.

Part Two is mainly concerned with the effects of population growth on average income per head. In most of the economiccum-demographic models that have been developed over the past 20 to 30 years, these effects are unfavourable, largely because it is assumed that with more children in the average family the rate of saving and capital accumulation will be lower, and that a higher proportion of capital investment will go towards duplication of facilities (more schools, for example), rather than increasing capital per head. As against this, Simon makes three main points. First, larger families may increase the willingness of individuals to save and invest. Second, there are likely to be significant gains from economies of scale, since total output will be higher. Third and most important, output per head will benefit from "the contribution of additional people to our stock of useful knowledge" (p.196): a larger population means not only more mouths and hands, but also more brains. His broad conclusion, which he argues is consistent with the facts of economic history, is that moderate as distinct from zero rates of population growth are likely to have favourable effects on income per head, at any rate in the longer run, in rich and poor countries alike.

In Part Three ("Beyond the Data") the argument is taken further than the issue of material progress alone, and other values are brought in. Simon holds that enabling an extra person to live and enjoy life has value in itself, and that the well-being of a society has to be defined with reference not just to the average standard of living of its members, but to their total numbers also. He makes a sharp attack on the values and assumptions of anti-natalist bodies, such as Planned Parenthood, and argues that there is no justification for trying to reduce rates of population growth, as distinct 
from enabling parents to obtain the size of families that they would wish.

Throughout the book Simon's own position, as summarized just above, is contrasted with the latter-day Malthusians whom he wishes to discredit. There are numerous quotations, some from learned articles and monographs, but most from popular books, newspaper articles and advertisements, designed to illustrate the whole range of contemporary pessimism. The style is kept deliberately informal and colloquial, while the author's convictions are often set out in a highly personal way. Now and then this mode of presentation becomes a little trying, but in general the argument is clearly and effectively conveyed, without either condescension or oversimplification. In view of the range and complexity of the topics that are covered, this is a considerable feat.

In judging the merits of Simon's argument, two distinct tests are relevant, corresponding to the two aims which the book tries simultaneously to achieve. The first aim is destructive: to undermine and cast doubt on current neo-Malthusian pessimism. The second is to offer an alternative view of the world, an acceptable analysis of events, relationships and trends. Not surprisingly perhaps, the author succeeds more completely with the former task than with the latter.

The process of demolition is carried out with skill and resource. In part, the prophets of doom are discredited by the various excerpts from their own works, many of which make sorry reading. But the main weight of the argument rests on the evidence of the past and on general economic reasoning, both of which are often neglected or undervalued by the pessimists, and which the author presents extremely well. Unfortunately, the views that he attacks are widely held and influential. By challenging them so effectively Simon has performed a real service.

When it comes to his alternative view of the world, there is more room for doubt. At a number of points the argument seems to me to be too unqualified or incautious, while in some respects it is less complete than it should be. For example, his generally admirable discussion of natural resources is marred by a failure to consider the possibility that oil is a special case. Because of what are often presented as facts of geology, it may be that the period of cheap oil was a historical accident, a bonanza which cannot be repeated. If this is so, and given the unique convenience and properties of petroleum as a fuel, a secular rise in the real price of oil is not at all to be ruled out; and it is insufficient to dismiss the increases of the 1970s, as Simon does, as being due simply to the machinations of OPEC. Moreover, because of its role in the world economy, and the uneven distribution of productive capacity and reserves, the effects of oil price increases are potentially much more damaging than in the case of other raw materials. Simon does not go into this, and his two chapters on energy are superficial.

As to population, a clearer distinction could have been made between two aspects of the question: the absolute size of a population, and its rate of growth. More space should also have been given to two arguments against rapid population growth: one is the possible congestion arising from higher densities, while the other is that a rapidly growing labour force may lead to a more unequal distribution of income. Again, Simon states correctly that a judgement on the net advantages of population growth may depend on how one weighs more distant costs and benefits in relation to those which are nearer in time. But he says nothing about how this valuation of time should be made, nor about the suitability of using for this purpose the actual rates of interest that are established in financial markets.

More worrying is an occasional tendency to rather serious overstatement. Thus in the concluding chapter, we are told that "The standard of living has risen along with the size of the world's population since the beginning of recorded time" (p.345). This is false. One can find phases of history - as for example in England from the mid-thirteenth century till around the end of the seventeenth - when a rise in population is thought to have led directly to a fall in real wages, and vice versa: the simple Malthusian model seems to fit the facts. It is probably only in the modern era that this inverse connection has been broken, first in the industrial countries and more recently in other parts of the world: possibly it holds good even now in some of the poorest and least developed countries. Here and at some other points of the argument, Simon has yielded to temptation: he makes overconfident generalizations about relationships that are subject to considerable variety and change.

Despite these reservations, the book is much to be recommended. It is possibly the best available modern treatment of the issues that Malthus raised.

P. D. Henderson is a Professor in the Department of Political Economy at University College London.

\section{The hunting of the rorqual}

\section{Arthur Bourne}

The History of Modern Whaling. By J.N. Tønnessen and A.O. Johnsen. Pp.798. UK ISBN 0-905838-23-8; US ISBN 0-52003973-4. (C. Hurst, London/University of California Press: 1982.) $£ 22.50, \$ 45$.

THE POPULAR image of whaling as the harpooneer, lance in hand, standing bravely on the prow of a row-boat ready to do battle with Leviathan, is enshrined in the writings of authors like Melville and Bullen. The picture is a romantic one but, as both those writers knew, whaling was far from romantic. It was - and its rump is a tough business, firmly based on hard commercial interests. If there is little romance in whaling, as compensation there is a world of fascination and of no period is this more true than when the new whaling industry was emerging from the old.

The modern epoch really began in Fobruary 1864 when a small steampowered vessel, the Spes et Fides, sailed out of Tønsberg in south-eastern Norway for the whaling grounds off Finnmark. It is the story of the unfolding of that modern history which is the subject of Den Moderne Hvalfangsts Historie, of which the volume under review is a muchcondensed English translation. In it the authors have cleverly drawn together the strands of the technical, sociological and financial developments of that period.

The birth of the modern whaling industry will always be associated with one man, the owner and skipper of the Spes et
Fides, Svend Foyn. Why he was to be the leading force and why Norway should have been the birthplace are interesting questions. As the authors show, the Americans dominated the old whaling scene and were experimenting with new methods at the same time as Foyn. Even his idea of combining an explosive harpoon fired from a cannon mounted on a steampowered boat was not original, and he was not the first man to realize that the future of whaling lay in the chasing, catching and processing of the great rorquals. The real answers to those questions lie not only in the technical inventiveness of the various contenders - of which there were many but also in the social and economic changes that were occurring at the time.

In the middle of the nineteenth century the Americans were looking increasingly inwards. The opening of the West with its vast prairies and potentially enormous mineral wealth seduced capital and labour away from the coast and the sea. In Norway the situation was very different. With little hinterland and an increasing population which the nation's industry and agriculture could not sustain, thousands of Norwegians, in common with many other Europeans, sought their futures in North America. By one of those quirks of fate, America's retreat from the sea opened up an opportunity for the Norwegians left at home. They were quick to fill the gap, and, combined with the expansion of sea-tradc generally, this provided the stimulus for the 